\title{
KOMPOSISI KIMIA DAGING UDANG VANAMEI DAN UDANG WINDU DENGAN SISTEM BUDIDAYA KERAMBA JARING APUNG
}

\author{
CHEMICAL COMPOSITION OF WHITE SHRIMP (Litopenaeus vannamei) AND TIGER \\ SHRIMP (Penaeus monodon) MEATS CULTIVATED IN FLOATING NET CAGE
}

\author{
Aldi Huda Verdian *1, Pindo Witoko ${ }^{1}$, Rahmadi Aziz ${ }^{1}$ \\ 1) Program Studi Budidaya Perikanan, Politeknik Negeri Lampung \\ Jalan Soekarno-Hatta No. 10 Rajabasa Bandar Lampung \\ *Surel : aldihudaverdian@polinela.ac.id
}

\begin{abstract}
One of the breakthroughs for increasing shrimp production is to utilize the sea with floating net cages. The objective of this study was to compare chemical composition of white shrimp (Litopenaeus vannamei) and tiger shrimp (Penaeus monodon) meats cultivated in floating net cage. The result in this study shows that white shrimp meat had higher protein and ash contents than had tiger shrimp meat. Proximate compositions in shrimp muscles are governed by many factors, including species, growth stage, feed and season.
\end{abstract}

Keywords : chemical composition, white shrimp (Litopenaeus vannamei), tiger shrimp (Penaeus monodon),

\section{PENDAHULUAN}

Budidaya udang vaname (Litopenaeus vannamei) dan udang windu (Penaeus monodon) di Indonesia telah cukup lama berkembang. Sebagai salah satu negara produsen utama udang dunia, Indonesia memerlukan upaya peningkatan produksi melalui intensifikasi dan ekstensifikasi budidaya. Saat ini sebagian besar proses budidaya dilakukan dengan menerapkan sistem budidaya intensif di tambak yang dicirikan dengan padat tebar yang tinggi dan penggunaan pakan tambahan secara maksimal serta sedikit atau tanpa pergantian air. Padatan yang tinggi dan meningkatnya input pakan buatan yang tinggi protein ke dalam sistem, akan memengaruhi kualitas air budidaya, baik dalam bentuk peningkatan padatan tersuspensi maupun dalam bentuk peningkatan limbah nitrogen yang berasal dari sisa hasil metabolisme dan sisa pakan yang tidak termanfaatkan oleh udang, hal ini akan meningkatkan resiko kondisi udang mudah mengalami stress dan akan memperlemah kondisi udang sehingga mudah terserang penyakit (Maulina et al. 2012).

Salah satu upaya peningkatan produksi yang dilakukan pemerintah Indonesia yaitu dengan mengembangkan budidaya udang di laut menggunakan media karamba jaring apung (KJA). Budidaya udang menggunakan KJA di laut memiliki kelebihan dibandingkan dengan budidaya udang di tambak diantaranya adalah sirkulasi air yang tinggi sehingga menyebabkan kualitas air yang optimal, limbah padatan yang tersuspensi tidak terakumulasi di sekitar karamba, serta dapat mengoptimalkan lahan budidaya (Zarain-Herzberg et al. 2010; Effendi et al. 2016; Verdian 2016).

Saat ini studi mengenai komposisi nutrisi udang yang dibudidayakan di laut masih sedikit. Sebelumnya studi mengenai perbandingan komposisi nutrisi udang vaname dan udang windu di 
tambak telah di lakukan (Sriket et al. 2006). Sehingga, studi ini bertujuan untuk membandingkan kandungan proksimat udang vaname dan udang windu dengan sistem keramba jaring apung di perairan laut Teluk Hurun Lampung.

\section{METODE}

Sampel udang laut berasal dari hasil budidaya selama 4 bulan menggunakan KJA Politeknik Negeri Lampung daerah Teluk Hurun, Hanura, Kabupaten Pesawaran. Sampel udang vaname yang digunakan berukuran 20,25 \pm 4,25 g dan udang windu sebesar 4,98 $\pm 2,34 \mathrm{~g}$.

Pengukuran komposisi kimia (Proksimat) menggunakan metode (AOAC 2005) di Laboratorium Teknologi Hasil Pertanian dan pengukuran rendemen daging dilaksanakan di Laboratorium Perikanan, Politeknik Negeri Lampung. Pengukuran rendemen dilakukan dengan cara mengukur masing-masing sampel daging, karapas dan jeroan dari persentase total bobot sampel udang.

\section{HASIL}

\section{Komposisi Kimia Udang}

Analisis proksimat dilakukan untuk mengetahui kandungan nilai nutrien secara kasar (crude) yang meliputi kadar air, protein, lemak, dan abu yang terdapat dalam bahan. Hasil analisis proksimat udang vannamei dapat dilihat pada Tabel 1.

Tabel 1. Komposisi kimia daging udang vaname dan windu

\begin{tabular}{lcccc}
\hline \multirow{2}{*}{ Komposisi Kimia } & \multicolumn{2}{c}{ Udang Vaname } & \multicolumn{2}{c}{ Udang Windu } \\
\cline { 2 - 5 } & $\begin{array}{c}\text { Berat Basah } \\
(\%)\end{array}$ & $\begin{array}{c}\text { Berat Kering } \\
(\%)\end{array}$ & $\begin{array}{c}\text { Berat Basah } \\
(\%)\end{array}$ & $\begin{array}{c}\text { Berat Kering } \\
(\%)\end{array}$ \\
\hline Kadar Air & 72,64 & 0 & 73,39 & 0 \\
Kadar Protein & 19,38 & 70,81 & 18,35 & 68,96 \\
Kadar Lemak & 0,82 & 2,99 & 0,86 & 3,24 \\
Kadar Karbohidrat & 6,10 & 22,29 & 5,73 & 21,55 \\
Kadar Abu & 1,07 & 3,90 & 1,66 & 6,25 \\
Kadar Serat Kasar & 0,78 & 2,85 & 0,45 & 1,71 \\
\hline
\end{tabular}

Hasil pengukuran yang diperoleh menunjukkan kadar air dalam udang sebesar 72,64\% pada udang vaname dan 73,39\% pada udang windu. Hasil pengukuran kadar protein, kadar lemak, kadar karbohidrat dan serat kasar tidak terdapat perbedaan secara signifikan. Hasil pengukuran kadar abu pada udang windu sebesar 6,25 \% lebih tinggi dibandingkan udang vaname sebesar 3,90 $\%$.

\section{Rendemen Udang}

Rendemen udang berupa daging, cangkang dan jeroan dapat dilihat pada Gambar 1. Gambar 1 menunjukan nilai rendemen daging udang vaname sebesar 71,62 \pm 3,70 \% dan udang windu sebesar $62,76 \pm 4,70 \%$. Jenis spesies udang yang berbeda mengakibatkan perbedaan hasil rendemen dan komposisi kimia daging udang yang diamati. 

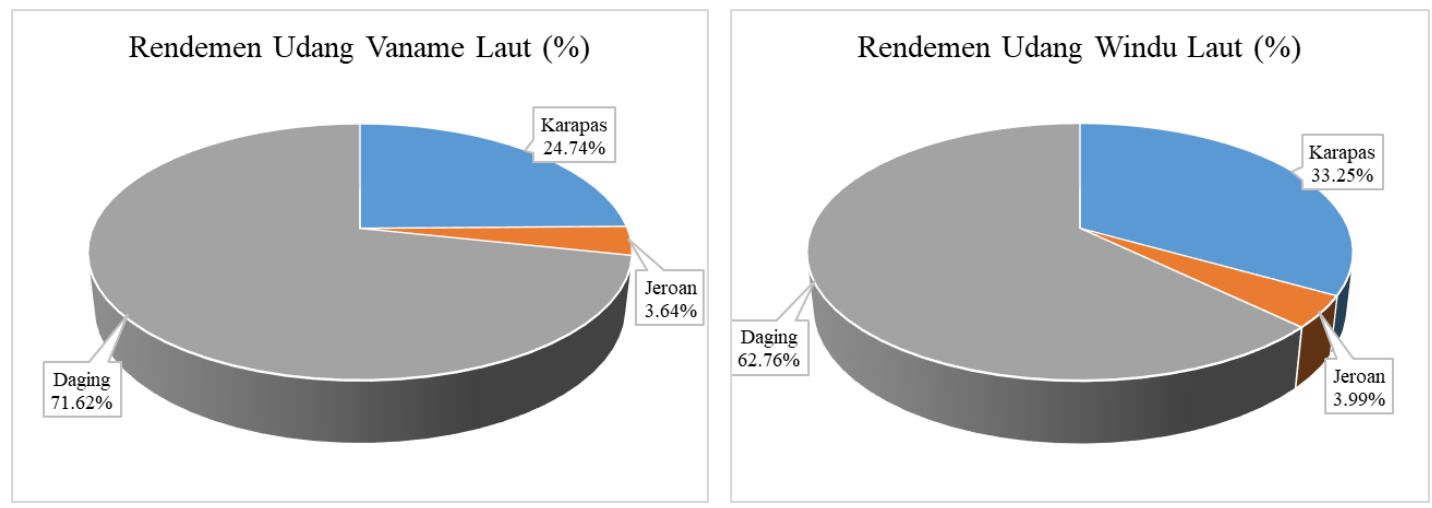

Gambar 1. Persentase rendemen udang vaname dan udang windu yang dipelihara di KJA

Perbedaan rendemen karapas pada udang vaname sebesar $24,74 \pm 4,66 \%$ dan udang windu sebesar 33,25 $\pm 4,46 \%$. Perbedaan rendemen jeroan pada udang vaname sebesar 3,64 $\pm 0,97 \%$ dan udang windu sebesar 3,99 $\pm 0,46 \%$.

\section{PEMBAHASAN}

Hasil studi menunjukan bahwa kedua jenis udang baik vaname maupun windu yang dibudidayakan di laut memiliki kadar protein yang cukup tinggi (Tabel 1). Hasil ini dapat mengindikasikan bahwa daging udang yang dibudidayakan di laut dapat dijadikan sebagai sumber asam amino yang baik. Hasil pengukuran proksimat menunjukan bahwa daging udang vaname memiliki kandungan protein yang lebih tinggi dibandingkan dengan udang windu, namun tidak terlalu signifkan perbedaannya. Ariyani et al (2007) menyatakan bahwa udang merupakan bahan makanan yang sangat mudah rusak karena memiliki kandungan kadar air dan protein yang cukup tinggi. Hasil pengukuran kadar air yang tinggi pada daging udang disebabkan oleh kemampuan bahan untuk mengikat air yang disebut water holding capacity (WHC) hal ini menunjukkan bahwa udang merupakan bahan pangan yang bersifat mudah rusak (high perishable food) (Effendi I, 2016).

Hasil pengukuran kadar abu menunjukan bahwa daging udang windu lebih tinggi dibandingkan dengan daging udang vaname hal ini juga sesuai dengan Sriket (2007) yang menyatakan bahwa daging udang vaname memiliki kadar abu yang lebih rendah dibandingkan dengan udang windu. Selain itu kadar abu dipengaruhi oleh kandungan mineral yang terdapat pada udang. Komposisi mineral yang terdapat pada setiap udang dipengaruhi oleh kondisi lingkungan perairan pada setiap sistem budidaya (Effendi I, 2016). Perbedaan komposisi proksimat daging pada kedua jenis udang dapat mempengaruhi kualitas sensorik dan masa simpan daging udang. Selain itu, pada studi sebelumnya menyebutkan bahwa faktor - faktor yang dapat mempengaruhi komposisi nutrient udang diantarnya adalah spesies udang, pertumbuhan udang, pakan dan musim (Sikorski, Kolakowska dan Pan, 1990; Karakoltsidis et al., 1995)

Perbedaan hasil rendemen daging pada udang vaname menunjukan hasil yang lebih tinggi dibandingkan udang windu, sedangkan udang windu memiliki rendemen karapas dan jeroan yang lebih tinggi dibandingkan udang vaname. Perbedaan ini mengindikasikan bahwa udang vaname memiliki masa molting yang lebih cepat sehingga memiliki pertumbuhan yang lebih tinggi dibandingkan dengan udang windu. Selain itu, dapat diindaksikan juga bahwa udang vaname memiliki proses osmoregulasi yang lebih baik. Di sisi lain berdasarkan habitat asli, udang vaname hidup pada ekosistem laut sedangkan udang windu hidup pada ekosistem estuary yang memiliki 
kondisi perairan dengan kadar salinitas yang fluktuatif sehingga pertumbuhan udang windu tidak setinggi pertumbuhan udang vaname.

\section{KESIMPULAN}

Daging udang vaname yang dibudidayakan di KJA memiliki kandungan protein yang lebih tinggi dan pertumbuhan yang lebih cepat dibandingkan daging udang windu yang dibudidayakan di KJA.

\section{DAFTAR PUSTAKA}

AOAC [Association of Official Analitycal Chemist]. 2005. Official methods of analysis of the Association of Analytical Chemist. Arlington, Virginia, USA: Published by Association of Official Analytical Chemist, Inc.

Ariyani F, Murtini JT, Indriati N, Dwiyitno, Yenni Y. 2007. Penggunaan glyroxyl untuk menghambat mutu ikan mas (Cyprinus carpio) Segar. Jurnal Fish. Sciencce. 9(1): 125-133.

Azhar MH, Eddy S, Kukuh N, Julie E. 2016. Organic Carbon Source and C/N Ratio Affect Inorganic Nitrogen Profile in the Biofloc-Based Culture Media of Pacific White Shrimp (Litopenaeus vannamei). Ilmu Kelautan. 21:23-28.

Effendi I. 2016. Budidaya Intensif Udang Vaname Litopenaeus vannamei di Laut: Kajian Lokasi, Fisiologis dan Biokimia [disertasi]. Bogor (ID): Institut Pertanian Bogor.

Karakoltsidis PA, Zotos A, dan Constantinides SM. 1995. Composition of the commercially important Mediterranean finfish, crustaceans, and mollusks. Journal of Food Composition and Analysis, 8, 258-273.

Maulina I, Handaka AA, Riyantini I. 2012. Analisis Prospek Budidaya Tambak Udang di Kabupaten Garut. Jurnal Akuatika. 3(1): 49-62

Sikorski ZE, Kolakowska A dan Pan BS. (1990). The nutritive composition of the major groups of marine food organisms. In Z. E. Sikorski (Ed.), Seafood: resources, nutritional composition and preservation (pp. 29-54). Florida: CRC Press.

Sriket P, Benjakul S, Visessanguan W, Kijroongrojana K. 2006. Comparative studies on chemical composition and thermal properties of black tiger shrimp (Penaeus monodon) and white shrimp (Penaeus vannamei) meats. Food Chemistry. 103: 1119-1207.

Verdian AH. 2018. Kinerja Produksi Udang Vaname Dan Rumput Laut Dalam Sistem IMTA Dengan Padat Tebar Ikan Baronang Berbeda [tesis]. Bogor (ID): Institut Pertanian Bogor.

Zarain-Herzberg M, Fraga I, Hernandez-Llamas A. 2010. Advances in Intensifying The Cultivation of The Shrimp Litopenaeus vannamei in Floating Cage. Aquaculture. 300:8792. 